\title{
Are Karaites Sceptics? The Jewish Perception of Karaism in Nineteenth Century Italy
}

In a note written by Sabato Morais (1823-1897), a rabbi native of Livorno and the founder of the Jewish Theological Seminary in the United States, and accompanying the text of Samuel David Luzzatto's Autobiography, ${ }^{1}$ we find this hagiographical portrait of a man whom he considered his spiritual mentor:

Nobody is more courageous than Luzzatto in expressing his opinions, so much courageous that sometimes he aroused against him a ruthless opposition. In all his writings Luzzatto, the believer, appears with a sharp sword to defend historical Judaism; piercing with his right hand the enemies of the traditions, repelling with his left hand the heretics who philosophize. ${ }^{2}$

While Morais is contributing to the transformation of Samuel David Luzzatto (1800 1865), also known by his Hebrew acronym ShaDaL, into a Jewish icon, making him a sort of archetypal Italian Jew, ${ }^{3}$ it is less clear to whom he is referring when he mentions the 'enemies of the tradition' and the 'heretics who philosophise.' I have claimed elsewhere that the so called 'heretics who philosophise' should be identified with the advocates of Jewish Reform, who, in their writings and in their deeds, challenged the status of revelation, the power of the rabbis, and the observance of legal precepts. ${ }^{4}$ For questioning the textual canon, religious authority, and shared practice of Judaism, orthodox antagonists, e.g. Luzzatto and to some extent also Sabato Morais, considered these reformers to be a threat undermining the legal, political, and social pact upon which Jewish life had relied for the previous two millennia, and were therefore accused of having been led astray by the 'sceptic spirit of the centu-

1 Samuel David Luzzatto, Autobiografia di Samuel David Luzzatto preceduta da alcune notizie storicoletterarie sulla famiglia Luzzatto a partire dal secolo decimosesto e susseguita da varie appendici (Padua: Crescini, 1882). The editor of this posthumous autobiography was Samuel David Luzzatto's son, the notary Isaia (1836-1898) with the collaboration of friends and pupils, such as Sabato Morais from Philadelphia and Samuel Vita Zelman (1808-1885) from Melbourne.

2 Luzzatto, Autobiografia, 70: 'Nessuno è più coraggioso di Luzzatto nell'espressione delle sue opinioni, coraggioso a tal segno ch'egli provocò talfiata contro di se' un'opposizione spietata. In tutti i suoi scritti il credente [S. D. Luzzatto] apparisce con una spada tagliente, per difendere il Giudaismo storico; passando da parte a parte colla sua mano destra i nemici delle tradizioni, respingendo colla sinistra gli eretici che filosofeggiano.'

3 Paraphrasing Alexander Altmann, "Moses Mendelssohn the Archetypal German Jew," in The Jewish Response to German Culture: From the Enlightenment to the Second World War, eds. Jehuda Reinharz and Walter Schatzberg (Hanover, NH: University Press of New England, 1991): 17-30.

4 Asher Salah, "Jewish Reform in Italy," in Wissenschaft des Judentums in Europe: Comparative and Transnational Perspectives, eds. Christian Wiese and Mirjam Thulin (Berlin: De Gruyter, forthcoming). 
ry. ${ }^{5}$ To counter the spread of reformist stances within Italian Judaism, intense and unprecedented activities dedicated to dogmatic interpretations of Judaism were carried out via, for instance, the printing of countless catechisms, ${ }^{6}$ the composition of treatises under the heading Dogmatic Theologies, ${ }^{7}$ and attempting to ascertain what constitutes the essence of Judaism. The term essence became extremely popular subsequently, particularly in the German speaking states at the turn of the century, attracting both Reformers and the Orthodox, who produced countless books and booklets bearing the title of Das Wesen des Judentums. ${ }^{8}$

The so-called 'enemies of the traditions' were actually the great majority of the Jews in Italy after the Emancipation, now having become, allegedly, 'indifferent' toward religious questions in general and abandoning any bond with the Jewish community. Together with 'scepticism', 'indifferentism' was a recurring complaint registered in the writings of rabbis whose synagogues and schools had been deserted by their members and pupils. Conservative and liberal figures of the Italian rabbinate naturally proposed differing remedies to this situation but all shared a similar diagnose of the situation.

In Mantua, one of the most important Jewish communities of Northern Italy, Rabbi Salomone Nissim (1781-1864), a staunch orthodox, described what he deemed the greatest danger for his coreligionists in these terms: 'another plague of the century, that has its root in the ignorance, is the cold indifference. ${ }^{9}$ His direct superior,

5 The expression 'spirito scettico del secolo' and similar ones are very common in Christian and Jewish works concerning religious and philosophical issues; cf., for instance, Salomon Munk, Palestina: descrizione storica, geografica e archeologica (Venice: Stabilimento nazionale, 1853), 1. It is important to stress that the term 'scepticism' does not refer only to an epistemology but concerns a general strategy to undermine authority and tradition and in some instances can be interpreted as atheism, agnosticism or even anarchism.

6 Cf. Gadi Luzzatto Voghera, "I catechismi ebraici tra Sette e Ottocento," in Le religioni e il mondo moderno, II. Ebraismo, ed. Davide Bidussa (Turin: Einaudi, 2008): 437-455.

7 The most important ones are written by Samuel David Luzzatto, Lezioni di teologia dogmatica (Trieste: Coen, 1863) and Elijah Benamozegh, Teologia dogmatica ed apologetica (Livorno: Francesco Vigo, 1877).

8 While in Germany this kind of literature was triggered mainly as a reaction to Adolf von Harnack, Wesen des Christentums (Leipzig: J. C. Hinrichs, 1900)-cf. the works of Isaac Breuer, Lehre, Gesetz und Nation. Eine historisch-kritische Untersuchung über das Wesen des Judentums (Frankfurt am Main: Verlag d. Israelit, 1914); Simon Mandel, Das Wesen des Judentums (Frankfurt am Main, 1904); Leo Baeck, Das Wesen des Judentums (Berlin: Nathansen und Lamm, 1905); Jacob Fromer, Das Wesen des Judentums (Leipzig: Hüpeden \& Merzyn, 1905); Hermann L. Strack, Das Wesen des Judentums. Vortrag gehalten auf der Internationalen Konferenz der Judenmission zu Amsterdam (Leipzig: J. C. Hinrichs, 1906) -, in Italy it was popularised by Samuel David Luzzatto who titled the central chapter of his Il giudaismo illustrato nella sua teorica, nella sua storia e nella sua letteratura (Padua: Bianchi, 1848) as "Essenza del Giudaismo."

9 Salomone Nissim, Appello di un rabbino nell'anno settuaginesimo nono di sua età agli amati suoi correligionari (Siena: Moschini, 1860): 'Altra piaga del secolo, che nell'ignoranza stessa ha radice, si è la fredda indifferenza.' On Nissim, see Mauro Perani and Gioia Liccardo, “Il testamento spirituale 
the chief rabbi of Mantua, Marco Mortara (1815-1894), who unlike Nissim was favourable to the possibility of introducing certain reforms to Jewish practice, differed in his explanation of the phenomenon though was in agreement with the facts. In a letter to the Leghorn Jewish community, he writes: 'it is not because of the lack of the religious sentiment that people make transgressions, but to excuse the transgressions they affect religious indifference. ${ }^{10}$

But in the theological debate in the nineteenth century there is a third category of Jews, related to the previous two, i.e. the Karaites, a religious movement founded in the eighth century in Babylon, who stirred considerable interest and preoccupation among Italian Jews as ambivalent objects of attraction and repulsion. ${ }^{11}$ This article is dedicated to the attempt to understand who these Karaites are and why did they become a polemical target in the theological debate of the nineteenth century.

\section{Karaites in the Early Modern Religious Debate}

Obviously, Karaites have been a target of Jewish religious polemic not just in Italy and not only in the nineteenth century. From the early Middle Ages, Jewish authors occupied themselves a great deal with Karaism and were usually directed by an antagonistic mindset toward them. The Karaites were, accused of scripturalism, i.e. of a literal reading of the Hebrew Bible. Resentment between Rabbanites and Karaites has been particularly fierce in Eastern Europe and Islamic lands where the two communities lived at close quarters with one an another and became intimately acquainted with one another's laws and regulations. In Western Europe under Christian rulers, the presence of Karaites was extremely scant and sporadic, hence debates concerning this minority faith primarily came about in two different historical settings. The first from the sixteenth to the beginning of the eighteenth century, the second in the nineteenth century when the study of Karaism emerged as a fully-fledged field of academic scholarship.

\footnotetext{
del rabbino mantovano Salomone Nissim," in Nuovi studi in onore di Marco Mortara nel secondo centenario della nascita, eds. Mauro Perani and Ermanno Finzi (Florence: La Giuntina, 2016): 98-112. 10 See the letter of June 4, 1867, edited in Asher Salah, L'epistolario di Marco Mortara (1815-1894), un rabbino italiano tra Riforma e Ortodossia (Florence: La Giuntina, 2012), 211: 'Non è per mancanza di sentimento religioso che si trascorre alle trasgressioni, ma si' per iscusare le trasgressioni che si affetta l'indifferenza religiosa.' Already in his youth, Mortara had alerted against the dangers of 'religious indifferentism' in his sermon Dell'indifferenza in fatto di religione (Mantua, 1839), considering it a problem coming from France. He was probably influenced by the essay of the abbé Hugues-Félicité Robert de Lamennais, Essai sur l'indifférence en matière de religion (Paris, 1817), translated into Italian by the countess Ferdinanda Montanari Riccini, and published in Modena in 1824.

11 For a comprehensive bibliography on the subject, see Barry Dov Walfish and Mikhail Kizilov, Bibliographia Karaitica: An Annotated Bibliography of Karaites and Karaism: Karaite Texts and Studies (Leiden and Boston: Brill, 2010).
} 
In the last two decades, much scholarly attention has been devoted to the instrumental role of the figure of the Karaite in early modern and modern European religious controversy. ${ }^{12}$ From these studies emerges the importance of Protestant Hebraists in introducing Karaism within the range of European erudition in the early modern era. The considerable curiosity concerning Karaites among Christian scholars, particularly Protestants, was ostensibly due to the analogy between Karaism and Reformed Christianity on the one hand, and Rabbinic Judaism and Catholicism on the other. This correlation recurs in the writings of Leiden university professors, such as the antiquarian Joseph Justus Scaliger (1540-1609), the exegete Johannes Drusius (1550-1616), the theologian Johannes Hoornbeek (1617-1666), or Jacobus Trigland the Younger (1652-1705). ${ }^{13}$ Karaism also became a central concern in millenarian circles all over Northern Europe, as in the works by the Scottish irenicist John Dury (1596-1680), correspondent of the Amsterdam rabbi Menasseh Ben Israel (1604-1657), and whose knowledge about the Karaites came mainly from the Christian kabbalist Johann Stephan Rittangel (1606-1652). ${ }^{14}$ Missions were send to the Karaites residing in the Polish-Lithuanian commonwealth for the purpose of gathering information concerning their customs and writings, and probably also for converting them to Christianity, such as the mission organised by the Christian Orientalist Gustav Peringer (1651-1710) from Uppsala, under the aegis of king Charles XI of Sweden.

In the second period of revival of interest for the Karaites, in the nineteenth century, Karaism was invoked by some scholars of the incipient Wissenschaft des Judentums, such as Abraham Geiger (1810 -1874), Isaak Markus Jost (1793-1860), Samuel Holdheim (1806-1860) or Isaac Hirsch Weiss (1815-1905), as the prototype of the

12 Cf. Jakob Petuchowski, "Karaite Tendencies in an Early Reform Haggada," Hebrew Union College Annual 31 (1960): 223 - 249; Johannes van den Berg, "Proto-Protestants? The Image of the Karaites as a Mirror of the Catholic-Protestant Controversy in the Seventeenth Century," in idem, Religious Currents and Cross-Currents: Essays on Early Modern Protestantism and the Protestant Enlightenment, eds. Jan de Bruijn, Pieter Holtrop, and Ernestine van der Wall (Leiden and Boston: Brill, 1999): 43-64; Daniel Lasker, "Ha-Qarai ke-Aher Yehudi" [Hebrew], Peamim 89 (2001): 96-106; idem, "Karaism and Christian Hebraism: a New Document,” Renaissance Quarterly 59.4 (2006): 1089-1116; Valerio Marchetti, "The Lutheran Discovery of Karaite Hermeneutics," in Una Manna buona per Mantova. Studi in onore di Vittore Colorni per il suo 92 compleanno, ed. Mauro Perani (Florence: Olschki, 2004): 433-459; Marina Rustow, "Karaites Real and Imagined: Three Cases of Jewish Heresy," Past and Present 197 (2007): 35-74; Golda Akhiezer, Historical Consciousness, Haskalah, and Nationalism among Eastern European Karaites [in Hebrew] (Jerusalem: Ben Zvi Institute, 2016).

13 Cf. Berg, "Proto-Protestants? The Image of the Karaites," 43-64; Akhiezer, Historical Consciousness, 106-116. I would like to thank Hanan Gafni for sharing with me his observations on these sources in his forthcoming Devarim she-be-'al-Peh, Devarim she-bi-Khtav: 'Al Tefisat ha-Torah she-be-'alPeh ve-Toldoteah ba-Mehqar ha-Yehudi ha-Moderni [Hebrew] (Forthcoming).

14 Cf. Richard Popkin, "The Lost Tribes, the Karaites, and the English Millenarians," Journal of Jewish Studies 37.2 (1986): 213-228. 
Jewish Reform they wanted to promote. ${ }^{15}$ For many Jews, extolling Karaism became a means to stress the existence of an historical and allegedly more rational alternative to talmudic Judaism.

While this periodisation is undoubtedly correct, it suffers from its excessively Germano-centric and Protestant-centric perspective, in as much as a problem that concerns much of the scholarship regarding the Haskalah and the Wissenschaft des Judentums too, which conflates Jewish European modernity with the German model. ${ }^{16}$ This has caused some scholars to underrate Catholic and Jewish interest in Karaites. ${ }^{17}$

However, Catholic scholars, such as Guillaume Postel (1510-1581), were the first to pave the way for greater European interest in the Karaites by other Christians and Jews. Later on, French Catholic intellectuals such as the Jesuit Nicolaus Serarius (1555-1609), the biblical scholar Jean Morin (1591-1659), Jacques Gaffarel (1601$1681)^{18}$, and last but not least, Richard Simon (1638-1712), author of an important appendix on the Karaites, ${ }^{19}$ published alongside his translation of Leon Modena's Riti Hebraici, admired the Karaites for their purportedly more critical approach to a tradition deemed to having been corrupted by rabbinic teachings. In Catholic polemics against Protestants it is not unusual to see the appropriation of the term Karaite by Catholics, attempting to demonstrate that Reform represented a deviate and later addition to the original evangelical message. ${ }^{20}$ Finally, at the times of the French Revolution, the Abbé Grégoire (1750-1831), the revolutionary leader and

15 Cf. Richard Popkin, “Les caraïtes et l'émancipation des juifs,” Dix-huitième siècle 13 (1981): 137147.

16 For recent studies of Wissenschaft that aim at expanding on the Germano-centric narrative of the history of the academic study of Judaism and Jewish history beyond German lands, see the forthcoming volume, Wissenschaft des Judentums in Europe: Comparative and Transnational Perspectives, eds. Christian Wiese and Mirjam Thulin (Berlin: De Gruyter, 2019); Louise Hecht, "The Beginning of Modern Jewish Historiography: Prague: A Center on the Periphery," Jewish History 19 (2005): 347-373; Nils Roemer, "Outside and Inside the Nations: Changing Borders in the Study of the Jewish Past during the Nineteenth Century," in Modern Judaism and Historical Consciousness: Identities, Encounters, Perspectives, eds. Andreas Gotzmann and Christian Wiese (Leiden and Boston: Brill: 2007): 28-53.

17 For instance, in her fundamental work on Karaite historiography Golda Akhiezer stresses that with the exception of Protestant Hebraists in the seventeenth and eighteenth century, the Karaite movement did not have any significant impact upon early modern Jewish literature until the beginning of the Science of Judaism in the nineteenth century; see Akhiezer, Historical Consciousness, 25. 18 On these scholars relationships with Italian Jews, see Avner Ben Zaken, Cross-Cultural Scientific Exchanges in the Eastern Mediterranean, 1560-1660 (Baltimore: Johns Hopkins University Press, 2010), in particular chapter three "Transcending Time in the Scribal East."

19 The author of this appendix was not Leon Modena as erroneously attributed in Ben Zaken, CrossCultural Scientific Exchanges, 98.

20 A later example of a catholic scholar presenting the Karaites has the true representatives of the original spirit of Judaism preserved intact by Roman Catholicism but altered and adulterated 'dallo spirito progressivo riformatore' ('the progressive reformist spirit') of rabbinism; see Niccolò C. Mariscotti, Il clero cattolico e la civiltà, vol. 2 (Florence: Galli, 1866), 150. Mariscotti mentions among the three main sects of Judaism at the times of Jesus the Pharisees, the Karaites, and the kabbalists. 
Roman Catholic prelate, took the Karaites as a model of what he deemed modern Judaism should be. ${ }^{21}$ The second claim regarding the lack of attention to the Karaite phenomenon within Jewish communities before the nineteenth century, cannot be taken at face value, in the knowledge of the deep doctrinal stir caused the Karaism accusations addressed to heterodox members within the Sephardic communities of Amsterdam, Hamburg and London in the seventeenth and eighteenth century, studied by Yosef Kaplan and Shalom Rosenberg. ${ }^{22}$

Oddly enough, contemporary scholarship seems to have overlooked the fact that, aside from the Northern European Sephardic communities, another important centre existed in the early modern era that produced a wide array of texts on the Karaites: Italy. In their appraisal of Karaism, Italian Jews, especially those gathered in Venice, differed from the Christian hebraists of their time and from Sephardic intellectuals living in the Netherlands. Not only was the first Karaite prayer book printed in Venice by Cornelius Adelkind in the Bomberg presses with the collaboration of local rabbanite Jews in $1528-1529,{ }^{23}$ but the Karaites also elicited much interest among the Venetian Jewish intellectual elite, such as Leon Modena (1571-1648), who wrote an entire tractate (now lost) on the Karaites, ${ }^{24}$ Joseph Solomon Delmedigo (1591-1655) whose occupation with Karaism is attested by his Sefer Elim (Amsterdam, 1629), ${ }^{25}$ and Simone Luzzatto (1580 - 1663), who devoted a few but significant paragraphs to Karaism in his Discorso circa il stato degli Hebrei (Venice: Giovanni Calleoni, 1638). ${ }^{26}$

21 Cf. Popkin, "Les caraïtes et l'émancipation des Juifs," 137-147.

22 Yosef Kaplan, "Karaites in the Early Eighteenth Century," in idem, An Alternative Path to Modernity: The Sephardi Diaspora in Western Europe (Leiden and Boston: Brill, 2000): 234-279; Shalom Rosenberg, "Emunat Hakhamim," in Jewish Thought in Seventeenth Century, eds. Isadore Twersky and Bernard Septimus (Cambridge, MA: Harvard University Press, 1987): 285-295.

23 Cf. Giovanni Bernardo De Rossi, Dizionario storico degli autori ebrei e delle loro opere, vol. 1 (Parma: Dalla reale stamperia, 1802), 3, says without giving his source that the Karaites tried to print a new edition of this liturgic work in Venice in 1713.

24 Cf. Johann Christoph Wolf, Bibliotheca Hebraea, vol. 3 (Hamburg: Christophorus Felginer, 1727), 1150, who mentions this tractate, whose existence has been challenged by some modern scholars although it is substantiated by a letter of Modena himself; see Leon Modena, She'elot u-Teshuvot Ziqnei Yehudah [Hebrew], ed. Shlomo Simonsohn (Jerusalem: Mossad ha-Rav Kook, 1956), 16: letter 37. To this lost work we should add the possibility of Modena being the author of the provocative libel against rabbinic culture and associated by Modena himself to Karaite arguments, as claimed by Talya Fishman, Shaking the Pillars of Exile: 'Voice of a Fool,' an Early Modern Jewish Critique of Rabbinic Culture (Stanford: Stanford University Press, 1997). Omero Proietti defends the attribution of this pamphlet to Uriel da Costa in his La città divisa: Flavio Giuseppe, Spinoza e i farisei (Rome: Il Calamo, 2003).

25 Cf. Ben-Zaken, Cross-Cultural Scientific Exchanges, 98-102. On Delmedigo's personal acquaintance with Lithuanian Karaites, see Stefan Schreiner, "Josef Shelomo Delmedigos Aufenthalt in Polen-Litauen," in An der Schwelle zur Moderne. Juden in der Renaissance, eds. Giuseppe Veltri and Annette Winkelmann (Leiden and Boston: Brill, 2003): 207-232.

26 The Discorso is included in the edition of Luzzatto's two main Italian works; see Simone Luzzatto, Scritti politici e filosofici di un ebreo scettico nella Venezia del Seicento, ed. Giuseppe Veltri (Milan: Bompiani, 2013), 3-106. 
While in Northern European Diaspora the label of 'Karaite' and the terms 'Sadducee' or 'Boethusian,' were used by rabbis such as Immanuel Aboab (1555-1628), Isaac Orobio de Castro (1617-1687), Moshe Hagiz (1671-1750), or David Nieto (16541728), to discredit those doubting the validity of the Oral Law, the Venetian rabbis appeared to have shared a less biased attitude towards Karaism. ${ }^{27}$ While ridiculing its practices and contradictions, Modena, Delmedigo, and Luzzatto are sensitive to the critical attitude and intellectual integrity of Karaism, and were prone to considering this group a full-fledged component of the Jewish nation and not necessarily its antagonist. In the famous sixteenth "Consideratione" of his Discorso, Luzzatto lists the Karaites as the fourth class of Jews, after the talmudists, the philosophers ('teologi filosofanti'), and the kabbalists. He deems the Karaites, despite their small number and their rejection of tradition, to be praiseworthy for their piety and for their grammatical expertise. In particular, Luzzatto recognises that in comparison to ancient sects within Judaism they were closer to the fundamental principles of faith of the rabbanite Jews for believing in the immortality and immateriality of the soul and accepting the existence of the angels. ${ }^{28}$

This may explain why, in the context of the controversy regarding Sabbateanism, Italian Jews, such as Samson Morpurgo (1681-1740), a physician and rabbi in Ancona, appear to have been reluctant to endorse the equation between the heresy of Shabbatai Zevi (1626-1676) and Karaism, as prompted by Moshe Hagiz of Amsterdam. ${ }^{29}$ It seems as if this ambiguous, and not entirely derogatory, appraisal of Karaism, so peculiar to the aforementioned Italian Jews, was due to their perception of the Karaites as a sort of sceptical sect that was wrong in its practical conclusions but correct in its intellectual challenges casting doubt on the conceit of reason. Certainly, much work remains to be done to ascertain the role of Italian Jews as intermediaries of information in early modern European debates of Karaism, exemplified by the case of the tobacco dealer and Sabbatean Jew Jonas Salvador of Pinerolo in Pied-

27 The image of Karaism in Italy seems to present some substantial differences from the way Marina Rustow describes the Sephardic diaspora in Northern Europe; see Rustow, "Karaites Real and Imagined," 36: "more than any other type of deviation from rabbinic norms, Karaism came to represent the denial of rabbinic authority. This was true even in its absence: the label of Karaism served as a category into which rabbinic and communal authorities placed all manner of biblicizing error and of resistance to rabbinic authority.'

28 Luzzatto, Discorso, 84v-85r: 'sono più corretti che li antichi Saducei, admettendo essi l'incorporalità et immortalità dell'anima, come anco assentiscono che vi siano angioli immateriali.' A very similar description of the Karaites, though more attentive to the present condition of the Karaites in the diaspora can be found in Leon Modena, Historia de gli riti hebraici (Paris, 1637), fifth part, chapter one. Were the anonymous work Qol Sakhal ('The Voice of the Fool') to be attributed to Modena we would find a much more enthusiastic appraisal of Karaism considered to be the only one that preserved the correct revelation of Moses and did not fall into decline.

29 Cf. Elisheva Carlebach, The Pursuit of Heresy: Rabbi Moses Hagiz and the Sabbatian Controversy (New York: Columbia University Press, 1990), 136, 149, 195. 
mont, who in 1670 became acquainted with Richard Simon in Paris, participated with him in an intense exchange of views on the Karaites. ${ }^{30}$

But where in Italy, a country where real Karaites have been absent at least since the vanishing of the last colonies in Sicily in the eleventh century, did Jews get their information from on Karaism ${ }^{31}$ The question is particularly relevant in understanding the position, both imaginary and real occupied by the Karaites in the writing of important representatives of the Science of Judaism in Italy in the nineteenth century.

\section{Italian Jews' Knowledge on Karaism in the Nineteenth Century}

Among the sources from which Italian Jews obtained their information on the 'Karaite question,' two were particularly popular in the nineteenth century, the Kuzari by Judah Halevi (c. 1075-1141) and the Mațeh Dan ve-ha-Kuzari ha-Sheni ('The Staff of Dan and the Second Kuzari') by David Nieto.

Judah Halevi deals with the Karaites in the third chapter of his philosophical dialogue devoted to the refutation of the teachings of Karaism and to the history of the development of the oral tradition..$^{32}$ Not only the first editions of the Hebrew version of the Kuzari by Judah Ibn Tibbon were printed in Italy, ${ }^{33}$ but also one of the most influential commentaries of Judah Halevi's work, the Qol Yehudah by Italian rabbi Judah Moscato (1530-1593), published posthumously in Venice in 1594 and since then frequently reprinted to accompany editions of the Kuzari. ${ }^{34}$ Without doubt, Italian Jews were not the only readers of the Kuzari which was widely studied and debated by intellectual circles across Europe. In the early modern era, the Kuzari was, in fact, used as a major source and standard reference for the discussions of Jewish sects among Christians and Jews.

30 Gershom Scholem, Sabbatai Șevi: The Mystical Messiah 1626-1676 (Princeton: Princeton University Press, 1973), 827-828.

31 According to Shmuel Spector, "The Karaites in Nazi-Occupied Europe as Reflected in German Documents" [in Hebrew], Pe'amim 29 (1986): 90-108, some Karaites are attested to have been in Italy in the first half of the twentieth century, mainly travelers passing through its ports e.g. the fifty Lithuanian Karaites mentioned by S. Zarhi, "Ha-Olim ha-Rishonim mi-Polin higi'u Arṣah be'Oniyyah" [Hebrew], Davar, December 2 (1949): 1, and the thirty-six refugees fleeing from Egypt in 1957 recorded in the Londonian Jewish Chronicle's article "1000 Jewish Refugees arrive in Italy," on January 11, 1957.

32 On the possibility that the Kuzari was originally composed as a response to a Karaite, see Daniel Lasker, "Judah Halevi and Karaism," in From Ancient Israel to Modern Judaism: Intellect in Quest of Understanding. Essays in Honor of Marvin Fox, eds. Jacob Neusner, Nahum Sarna, and Ernst Frerichs (Atlanta: Scholars Press, 1989): 111-126.

33 See Fano, 1506, Venice 1547, and Venice 1594 containing Moscato’s Qol Yehudah.

34 On Moscato intellectual background, see Giuseppe Veltri and Gianfranco Miletto, eds., Rabbi Judah Moscato and the Jewish Intellectual World of Mantua in the 16th-17th Centuries (Leiden and Boston: Brill, 2012). 
After a period of relative neglect in the eighteenth century for its anti-rationalist stances, the Kuzari benefited from a resurge in interest in the following century. Adam Shear in his work on the Rezeptionsgeschichte of the Kuzari stresses 'the wide appeal of the book to all sides of the increasingly fragmented Jewish body politic' all over Europe in the age of the Wissenschaft des Judentums. ${ }^{35}$ Mainly focussing on the Central and Northern European context, Shear's book sporadically refers to Italian Jews, but his observations concerning the importance of Halevi and the Kuzari in maśkil literature and among scholars of Judaism can be extended to Italy as well.

Aside from some rather marginal mentions of the Kuzari by the Mantuan maśkil and traveller Samuele Romanelli (1757-1814), ${ }^{36}$ Judah Halevi became standard reading for educated Italian Jews, as demonstrated by the inclusion of the Kuzari in the educational programme for advanced students elaborated by Elia Morpurgo (c. 1731/ 40 -1801) of Gradisca and published in the Berlin journal, Ha-Meassef, in 1786 under the title Mikhtav mi-Eliyyahu. ${ }^{37}$ In the official curriculum of the Collegio Rabbinico, the rabbinic seminary of Padua, only the Kuzari with commentary by Moscato is featured as compulsory reading for students in theology classes, although the original programme made up by Isaac Samuel Reggio in the 1820s also referred to Maimonides' Guide of the Perplexed, later eliminated allegedly containing 'principles of Greek philosophy, now rejected. ${ }^{38}$ According to the 1867 program of studies of the rabbinical college of Leghorn, a rival institution to the seminar in Padua and more oriented toward mystical studies than to the spirit of the Wissenschaft des Judentums, students in theology were given the choice to be tested either on the Kuzari, or on Josef Albo's Sefer ha-'Iqqarim and Saadiah Gaon's Sefer ha-Emunot ve-ha-De ot. ${ }^{39}$

35 Adam Shear, The Kuzari and the Shaping of Jewish Identity, 1167-1900 (Cambridge and New York: Cambridge University Press, 2008), 249.

36 Samuele Romanelli, Masa be-Arav [Hebrew] (Berlin: Hinukh Nearim, 1792), thirteenth chapter, mentions the second essay, paragraph 26, of the Kuzari on sacrifices; idem, Grammatica ragionata ebraica con trattato ed esempj di poesia (Trieste: Stamperia Governiale, 1799), where he quotes extensively from Halevi's poetry. Shear, The Kuzari, 244, also mentions the possibility of Romanelli having served as one of the proofreaders of Joseph Hrashantsky's editon of the Kuzari (Vienna, 1795). On Romanelli and Haskalah, see my introduction to the Italian edition of Samuele Romanelli, Visioni d'Oriente (Florence: La Giuntina, 2006).

37 Cf. Asher Salah, “'Bein Ghevule Ashkenaz VeItalia': Elia Morpurgo nel contesto delle riforme scolastiche nelle Unite Contee di Gradisca e Gorizia tra Sette e Ottocento," in Cultura ebraica nel Goriziano, ed. Marco Grusovin (Gorizia: Istituto di Storia Sociale e Religiosa, 2007): 101-123.

38 'Principi di filosofia greca in essa introdotti e presentemente obbliterati.' Cf. Nikolaus Vielmetti, "Das Collegio Rabbinico von Padua," in Wissenschaft des Judentums: Anfänge der Judaistik in Europa, ed. Julius Carlebach (Darmstadt: Wissenschaftliche Buchgesellschaft, 1992): 12-13, 54-57, and Maddalena Del Bianco Cotrozzi, Il collegio rabbinico di Padova. Un'istituzione religiosa dell'ebraismo sulla via dell'emancipazione (Florence: Olschki, 1995), 153.

39 Cf. Alfredo S. Toaff, “Il collegio rabbinico di Livorno,” La Rassegna Mensile di Israel 12 (1938): 188. 
The popularity of the Kuzari is attested to by at least two Italian translations, one by the chief rabbi of Florence, David Maroni $(1810-1888),{ }^{40}$ the second by Cesare Foà $(1833-1907)$ in $1872 .{ }^{41}$ Added to these two literary achievements are the numerous renditions of Halevi's poetry into Italian in the nineteenth century by towering figures of Italian Jewish intellectual life e.g. Cesare Rovighi (1820 - 1890), ${ }^{42}$ Salvatore De Benedetti (1818-1891), ${ }^{43}$ or Giuseppe Barzilai (1824-1902). ${ }^{44}$ The most important representative of this Halevian revival is undoubtedly Samuel David Luzzatto whose affection for Halevi's poetry appears throughout his oeuvre, from the publication of a poetic anthology of Judah Halevi, with notes and an introduction, under the title of Betulat Bat Yehudah (Prague, 1840), to the vocalised and corrected edition of the Diwan's eighty-six religious poems, with a philosophical commentary and introduction, published in Lyck in $1864 .^{45}$

Erudite correspondences of Italian Jewish scholars shed light upon their obsessive search and interest for any extant commentary of the book, such as Judah Moscato's, Qol Yehudah, Nathanel Caspi’s 'Edut le-Yiśrael, or Salomon de Lunel's alias Salomon Vivas, Hesheq Shelomo. ${ }^{46}$ The fact that personalities with radically different approaches to Judaism, such as the mystical Elijah Benamozegh (1822-1900) and the

40 This manuscript translation is mentioned in Maroni's testament published in Lionella Viterbo, Spigolando nell'archivio della comunità ebraica di Firenze (Florence: La Giuntina, 1997), 132.

41 Il Cosarì: opera scritta in arabico da Giuda Levita, spagnuolo; recata in ebraico da Giuda ben Tibbón, e volgarizzata da Cesare Foà (Casalmaggiore: Aroldi, 1872).

42 Cesare Rovighi's translation of a hymn by Halevi from a manuscript belonging to the Paduan Giuseppe Almanzi was published in Rivista Israelitica 1.5 (1846): 285-287.

43 Salvatore De Benedetti, Canzoniere Sacro di Giuda Levita (Pisa: Nistri, 1871). As a gift for the wedding Zabban-Pardo Roques, De Benedetti published Un epitalamio ebraico di Giuda Levita (Pisa: Nistri, 1891). A later version of selected poems was conducted by the rabbi of Soragna, Aldo Sorani, Giuda Levita, poesie scelte, preface by Hayim N. Bialik (Reggio: Riccardo Bondavalli, 1913).

44 At the end of his translation of the Lamentations of Jeremiah, I treni di Geremia, traduzione letterale dal testo ebraico in versi italiani con note originali (Trieste: Coen, 1867), Barzilai included also his poetic version of the Sioneide, encouraged by Lelio della Torre who had already published his own version of this elegy by Halevi (Abul Hassan), now collected in the posthumous Scritti Sparsi, vol. 1 (Padua: Prosperini, 1908), 375-390.

45 Cf. Irene Kajon, "The Problem of Divine Justice in Samuel David Luzzatto Commentary to the Diwan of Jehuda Ha-Levy," in Jewish Studies at the Turn of the Twentieth Century, vol. 2: Judaism from the Renaissance to Modern Times, eds. Judit Targarona Borrás and Angel Sáenz-Badillos (Leiden and Boston: Brill, 1999): 48-53.

46 See, for instance, Marco Mortara's letters to Samuel David Luzzatto, June 27, 1855, July 15, 1855, August 6, 1856, and December 29, 1856, and to Moritz Steinschneider of September 8, 1859 and again May 7, 1862 and August 24, 1865, concerning the project of printing these two commentaries from the collection of the chief rabbi of Mantua; edited in Salah, L'epistolario di Marco Mortara, 95-98, 147-150. Luzzatto corresponded intensively with Gideon Brecher (1797-1873) on his works about the Kuzari published in Prague in 1838-1840. 
anti-kabbalistic Samuel David Luzzatto, ${ }^{47}$ shared an unblemished fondness for Judah Halevi's oeuvre, can be explained as a survival of a characteristic Italian desire from the late Renaissance on to harmonise a moderate Maimonidism with a fideistic approach to religion influenced by Halevi. ${ }^{48}$

However, Halevi's success among Italian Jews cannot be separated from his defence of the foundational value of the Oral Law and the traditional building of Jewish faith. This also explains the strong engagement of Italian Jewish scholars with the Matteh Dan written by David Nieto a Venetian rabbi, living in London. ${ }^{49}$ This book was published simultaneously in Hebrew and Spanish in London in 1714, along with a separate edition in Hebrew and another exclusively in Spanish. While the first Kuzari was a defence of the Written Law, David Nieto's second Kuzari sets out to offer arguments in favour of the authenticity of the rabbinical tradition, against the attacks of the Karaites. Needless to say, these imaginary Karaites have little or nothing to do with the real Karaite communities living in Lithuania, Crimea and different parts of the Ottoman empire during that time. The Karaites David Nieto targets are none other than religious dissidents, mostly of Converso origin, influenced by a critical approach toward the Oral Law (torah she-be-'al-peh) of thinkers such as Uriel da Costa (c. 1585-1640), Juan (Daniel) de Prado (c. 1612-c. 1670), and most famously Baruch Spinoza (1632-1677). It is noteworthy that, although neither Spinozism nor Karaite communities in the East were apparently of great concern for Italian Jews in the following century, the Matteh Dan, which had been already partially translated by Aviad Sar Shalom Basilea (c. 1680-1743/9), rabbi of Mantua, in the first half of the eighteenth century, ${ }^{50}$ was rendered into Italian in at least two integral translations; one by the aforementioned rabbi David Maroni in Florence, the other carried out between 1843 and 1845 under the title Dissertazione e difesa della legge orale ('Dissertation and Defence of the Oral Law') 1846 by Eliseo Pontremoli (1778-1851), at that

47 Luzzatto's critical comments to the first volume of Gideon Brecher's 1838 edition of the Kuzari were deemed important enough by the editor to be included in the second volume published the next year.

48 Elijah Benamozegh explicitly reminds the common ground of Maimonides' and Halevi's perception of Christianity and Islam in his Teologia dogmatica ed apologetica (Livorno: Vigo, 1877), 272, and Israele e l'umanita. Il mio credo (Pisa: ETS, 2002), 160: 'Credo come insegnano Giuda Levita e Maimonide che il cristianesimo e l'islamismo sieno grandi avviamenti all'organamento definitivo religioso dell'umanità, la quale sarà perfetta solo quando accetterà dalle mani dell'antico Israele la semplice religione laicale e razionale detta Noahide,' and see also his Israël et l'Humanité (Paris: Leroux, 1914), 176: 'Les rabbins, entre autres Maimonide et Juda Halevi, en ont jugé ainsi et ils nous disent qu'il existe à chaque epoque une aspiration messianique correspondant à la tendence universaliste qui ne cesse de travailler au sein de l'humanité.'

49 The popularity of the book in the nineteenth century, outside Italy, is attested also by the versions into other European languages: in English by Louis Loewe, The Rod of Judgment (London: Wertheimer, 1842) and the manuscript version by Elias Hiam Lindo (1783-1865) made in 1853 and now preserved in the manuscripts Ms HUC JIR Cincinnati and Ms Montefiore 307. In the Jewish Theological Seminary, New York, there can be found a translation in Yiddish; see Ms New York, JTSL, 2390. 50 A version of it is extant in a Cambridge manuscript. 
time chief rabbi of Nice in the Kingdom of Piedmont..$^{51}$ Both translations circulated in manuscripts. In 1819 the rabbi Avtalion Lampronti of Ferrara wrote a philosophical treaty and commentary of the Mațeh Dan titled Wikkuah 'al 'Olam ha-Levanah veSha'ar Kokhvei ha-Lekhet ('Discussion on the Lunar World and on the other Planets'), devoted to the discussion of the relationship between science and faith, taking its cue from the fourth chapter of Nieto's work. ${ }^{52}$

Aside from the work's status as a reference guide to Jewish thought, it is clear that the interest manifested by Italian Jews concerning Halevi and Nieto does not derive so much from the factual information concerning the Karaites in their oeuvre, but from the possibility of providing an apology of rabbinic Judaism. However, the malleability of the figure of the Karaite, cut off from any concrete reference to the real representatives of this community, allowed its appropriation and instrumental use in different historical contexts. In the nineteenth century, in a context of civil emancipation of the Jews and their progressive integration within society as a whole, Karaism reappears in the writings of Italian Jews attempting to define the characteristics and the role of Judaism in modernity. But while in the early modern era Jews tended to associate Karaism with deistic postures within the Jewish community and rationalist attacks against tradition, in the nineteenth century Karaites were increasingly singled out as a specular image of contemporary Jewish reform. Hence, Karaites are placed in the hot seat for the novelty of their doctrines and ignorance of Judaism, rather than for their alleged challenges against the Oral Law.

\section{The Italian Wissenschaft des Judentums, the Reform and the Karaites}

In the nineteenth century, the Karaites return to the fore in Jewish intellectual debate in a completely new context dominated by the opposition between Reform and Orthodoxy. Michael Meyer has noted that 'by reviving interest in Samaritans, Hellenizers, Essenes, Sadducees, and Karaites, Reformed Jews were able to challenge the association of Judaism with Pharisaism, whose extension was the rabbinism that reigned at the time. ${ }^{53}$ Therefore it is no surprise that the most often quoted works favourable to the Karaites are to be found among Reformers. Abraham Geiger, for instance, explicitly referred to the Karaites as the prototype of the Reformed Jew. Conversely, in the orthodox camps, Karaites are accused of all the evils of modernity, irreligiosity and assimilation. The Galician rabbi and scholar Solomon Judah Rapoport

51 See Ms Paris, Library of the Alliance Israélite Universelle, 254. On Pontremoli, see Asher Salah, "Judaism as a Moral Theology: the Work and the Figure of Elisha Pontremoli," Zakhor, nuova serie 1 (2017): 101-129.

52 Ms Valmadonna 156.

53 Michael Meyer, Judaism Within Modernity: Essays on Jewish History and Religion (Detroit: Wayne State University Press, 2001), 50. 
(1786-1867) compared the strife and animosity of the Jewish reformers with the rift introduced within Judaism by Karaism and Sabbateanism. ${ }^{54}$ Azriel Hildesheimer (1820 -1899) reintroduced the use of writing the name of the followers of Karaism in Hebrew as Qara'im with an 'Ayin instead of with an Alef, insisting by such of a device on the divisive nature of this sect within Judaism (the Hebrew root Q.R.A means 'to rip'). Examples of this attitude against and in favour of 'Karaism' are widespread to such an extent that the Karaites became what Daniel Lasker called the 'Jewish other' par excellence. ${ }^{55}$

Sometimes, the term 'Karaite' could be used by Reformed Jews as a double-edged polemical weapon against conservative rabbis. Therefore, reformers such as Joseph Aub (1804-1880) or the aforementioned Abraham Geiger, in whose writings the word 'Karaite' is a very ambivalent concept and depends on his polemical targets, sometimes accuse their orthodox counterparts of being Karaites for not being able to adapt to the changing situation of Jewish life and sticking to the letter of the Talmud. ${ }^{56}$

What all these uses of the word 'Karaite', pejorative or sympathetic, have in common, is that the Karaite has become the figure of a fractured Judaism in two opposite camps. It is worth quoting Marcus Jost's exemplary image of the Karaites: 'Die Karaiten [...] behaupten [...] gegen die übrigen Juden dieselbe Stellung, wie die Protestanten gegen die Katholiken, und die Schiiten gegen die Sunniten. ${ }^{57}$ In the German cultural domain, the Jewish world is therefore perceived to be as irremediably divided as Christianity and Islam, torn by an inner war of religions.

Without insisting or believing in an Italian Sonderweg, the Karaite question in Italy is posited in a quite different form than in German lands. At the turn of the nineteenth century, even prior to the mobilisation of the first and second Kuzari by the nascent Orthodoxy and Reformers in German speaking lands and in England, ${ }^{58}$ Karaites elicited a good deal of curiosity among Italian Jews. This could well have been the background for the rumours widely circulated in Europe claiming Italian Jews were trying to implement substantial reforms of the Jewish law inspired by the spirit of Karaism. The rumours reached Abbé Henry Grégoire, and Italian rabbis were compelled to issue blunt disclaimers dismissing such allegations. ${ }^{59}$ Nevertheless, Gré-

54 Solomon Judah Rapoport, Tokhahat Megulla [Hebrew] (Frankfurt am Main, 1845), 1.

55 Daniel Lasker, “Ha-Qarai ke-Aher Yehudi” [Hebrew], Peamim 89 (2001): 96-106.

56 Geiger defended himself against the charges of Karaism addressed to him by some Orthodox authors by labelling them as 'Talmud-Karaites'.

57 Marcus Jost, “Neue Berichte über die Karaiten und deren Geschichte,” Israelitische Annalen 28 (1839): 217.

58 For these cultural areas the phenomenon has been analysed by Shear, The Kuzari, 257-261. 59 They were first published in the Staats- und Gelehrte Zeitung des Hamburgischen unparteiischen Correspondenten 57 (1796). On this episode, cf. Ulrich Wyrwa, Juden in Toskana und in Preußen im Vergleich. Aufklärung und Emanzipation in Florenz, Livorno, Berlin und Königsberg i.Pr. (Tübingen: Mohr Siebeck, 2003), 84. Cf. also Jacob Katz, Out of the Ghetto: The Social Background of Jewish Emancipation, 1770-1870 (Syracuse, NY: Syracuse University Press, 1973), 153; Renzo De Felice, "Per una storia 
goire's work praising the allegedly 'Karaite bent' of Italian Jews was translated into Italian by the Piedmontese Jew Salomon Isaac Luzzati titled Osservazioni sullo stato degli ebrei in Francia e Germania (Casale Monferrato: Zanotti Bianco, 1806), ${ }^{60}$ and the Jewish press of the period reviewed it favourably. ${ }^{61}$

At around the same time Abraham Vita de Cologna (1755-1832), vice-president of the Napoleonic Sanhedrin in 1808 and Great Rabbi of France, a post he was to hold until 1826, wrote a self-defined 'anti-Karaite' treatise, that survived only in a 1820 translation from French into Hebrew, titled the Qera ha-Gever ('The Cockcrow'), by Elisha Pontremoli. ${ }^{62}$ Posing as a history of the Karaites and their literature, which to a large degree it is, the Qera ha-Gever contains many anti-Christian remarks and constitutes a late offspring of a kind of apologetic literature in defence of the Oral Law against the criticism of Christian and Jewish sceptics. In choosing to translate this work into Hebrew clearly reveals Pontremoli's involvement in religious polemics, a subject to which he devoted a short text, Wikkuah Socrati be-'Inyanei ha-Emunah ('Socratic Dialogue on Faith'), and his engagement in Jewish apologetics against those inclined to reform Judaism in the name of a restoration of the biblical purity, which the orthodox camp perceived as modern manifestations of Karaism. It is no coincidence that Pontremoli defines the despised Voltaire as 'a modern Sadducee.'

Despite this polemical attempt at disqualifying Karaism's claims to be the authentic representative of Judaism, Cologna's work in Pontremoli's translation makes a clear distinction between Karaism, as a sect of Judaism in the times of Geonim and contemporary Karaites, described in the eight chapter as 'much less distinct from rabbanite Jews today than they were in the past,' expressing the hope of a reconciliation with them in the near future, countering Christian attempts to increase the gap between the two Jewish groups. Cologna's treatise demonstrates a greater accuracy and deeper knowledge of real Karaism and the Karaite diaspora, and along with the traditional attacks to their faith present detailed description of their literature, their beliefs and their customs.

This is neither the first nor the only instance of an academic and less biased attitude concerning Karaism and Karaites. An earlier example of the curiosity attracted

del problema ebraico in Italia alla fine del XVIII e all'inizio del XIX. La prima emancipazione," Movimento Operaio 5 (1955): 681-727; Attilio Milano, Storia degli ebrei in Italia (Turin: Einaudi, 1963), 345; Lois C. Dubin, "Triest and Berlin: The Italian Role in the Cultural Politics of the Haskalah,” in Toward Modernity: the European Jewish Model, ed. Jacob Katz (New York: Routledge, 1997): 207208. See also the correspondence between Ricci and Grégoire in Maurice Vaussard, Correspondence Scipione de Ricci-Henry Grégoire (Florence: Sansoni, 1963).

60 Luzzati who also translated classics of Hebrew literature into Italian, such as the Tofteh Arukh by Moshe Zacut, L'inferno preparato (Turin, 1819), later converted to Catholicism took the name Amedeo Luzzati Valperga and published a periodical against the Talmud, Osservatore talmudico: giornale periodico (Turin: C. Sylva Tipografo, 1827).

61 As late as in 1880 we find positive reviews of this work. See, e. g. the Italian Jewish journal printed in Corfu but emanating from the Rabbinical College in Padua, Mosé 3 (1880): 297.

62 Ms Moscow, Russian State Library, Guenzburg 1440. 
by this religious group is evidenced in the biblical studies inspired by the new methods of philology and textual criticism is inarguably the precious collection of Karaite manuscripts collected by the Venetian rabbi Jacob Raphael Saraval (1708-1782) in the course of his numerous travels throughout Europe. ${ }^{63}$ Saraval provided the abbot Giovanni Bernardo De Rossi (1742-1831), professor of Oriental languages at the University of Parma, with the main body of information of Karaism that appeared in his encyclopaedic work on the history of Jewish literature. De Rossi was able to correct and add new sources to the classical textbooks on Karaism written by Jacobus Trigland, Johann Gottfried Schupart (1677-1730), Gustav Peringer and Johann Christoph Wolf (1683-1739) thanks to Saraval's erudite cooperation, from whose collection he purchased several Karaite manuscripts for the Palatine library in Parma. ${ }^{64}$ Another bibliophile and book collector, Moise Beniamin Foà (1730 -1822), an important Jewish scholar and merchant from Reggio well connected to the European academic networks, was able to bring part of Saraval's Karaite collection into the library holdings of the Duchy of Modena. ${ }^{65}$

A very positive assessment of Karaism can be found in the chapters thirteen and fourteen of the reform project designed by Aron Fernandez (1761-1828) (or Fernando -as he signed all of his works to Italianize his Iberian patronym) Progetto filosofico d'una completa riforma del culto e della educazione politico-morale del popolo ebreo (Tibériade, 1810; vere Florence: Marenigh, 1813) from Leghorn. Fernandez was convinced that 'Karaites agree with the rest of the Jews in what concerns the fundamental points of religion. ${ }^{96} \mathrm{He}$ admired their faith unburdened of useless practices and dangerous superstitions that had entered into Judaism over centuries of wanderings among idolatrous cultures, but criticised Karaism for its 'austerity that makes it in many parts almost impracticable. ${ }^{67}$

Despite a current image that is to be proven incorrect by recent Karaism scholarship, Fernandez was among the first scholars to understand that Karaites, were not adepts of a pure literal reading of the Bible for they accepted parts of the Masoretic interpretation of the Scriptures, and therefore could not be assimilated, based on the principle of sola scriptura, into Protestant hermeneutics. Fernandez is fully aware that Karaism is far from being a deistic and rational form of Judaism unlike the ver-

63 A description of his travel to the Netherlands can be found in the seven letters included in Jacob Raphael Saraval, Viaggi in Olanda (Venice: Zatta, 1807).

64 Cf. Giovanni Bernardo De Rossi, Dizionario storico degli autori ebrei e delle loro opere (Parma: Dalla reale stamperia, 1802), 121.

65 Cf. Giovanni Bernardo De Rossi, Annales hebraeo-typographici ab anno MDI ad MDXL digessit notisque hist.-criticis ab auctore instructi (Parma: Carmignani, 1799), 34.

66 Aron Fernandez, Progetto filosofico d'una completa riforma del culto e della educazione politicomorale del popolo ebreo (Tibériade, 1810; vere Florence: Marenigh, 1813), 184: 'I caraiti convergono in quanto riguarda i punti fondamentali della religione con gli altri ebrei.'

67 Ibidem, 198: 'Austerità che la rende in moltissime parti pressoché impraticabile.' 
sion of it he wishes to spread among his contemporaries and warns against an excessive idealisation of Karaism. ${ }^{68}$

Fernandez found an admirer of his radical project of reform in the otherwise moderate and observant rabbi of Gorizia, Isaac Samuel Reggio (1784-1855), a main figure of the Wissenschaft des Judentums in Italy and one of the founders of the rabbinical college of Padua. In 1852, Reggio published, under the title Behinat ha-Qabbalah ('Examination of the Tradition'), the work that he attributed to Leon Modena, the Qol Sakhal ('The Voice of the Fool'), a text that mentions the Karaites in highly favourable terms. According to Hanan Gafni, that very particular kind of Karaism found in Reggio's writings concerns the legal authority of the Talmud, considered by Reggio as purely theoretical, bearing no consequences for establishing the Halakhah. ${ }^{69}$ The only binding text for Reggio was the Mishnah, thus relativizing the reverence the Talmud was given by Jews in the Middle Ages in the Diaspora. For this reason Solomon Judah Rapoport attacked Reggio dubbing him a 'Karaite'.

Besides Reggio, another central figure of Italian Judaism in the nineteenth century, Samuel David Luzzatto, displayed an intense interest for Karaite scholarship and history. Like Reggio, Luzzatto corresponded with the Russian Karaite Abraham Leonowicz $(1780-1851){ }^{71}$ Luzzatto deals lengthily on the origins of the Karaites in his lessons of Jewish history, originally delivered during the academic year 1830 - 31 at the rabbinical college in Padua but published only two decades later. ${ }^{72}$ His main goal is to demonstrate, against the Kuzari author's opinion and the seventeenth century Dutch reform theologian Jacob Trigland, that Karaism is posterior to the constitution of rabbinic Judaism. The question is not only a scholarly diatribe, but also who is to be considered the representative of the authentic and original Judaism and who is but a later, corrupted, reformed version of it. Luzzatto writes:

[...] that the Karaites, not the Rabbanites, are to be identified with the new and reformed Jews. [...] The Karaites answer that the talmudists have often mentioned their sects, but that in their hatred they have confused it with the Sadducees. Consequently, some contemporary Rabbanites, influenced by their ignorance or by their hatred, still confuse the Karaites with the Sadducees. ${ }^{73}$

68 Ibidem, 196: 'Bisogna non lasciarsi trascinare dall'eccesso condannabile di deferire ciecamente a suoi errori nella ghisa medesima che approvate abbiamo le sue massime.'

69 Hanan Gafni, Pshuțah shel Mishnah. 'Tyyunim be-Heqer Sifrut Hazal be-'Et ha-Hadashah ("The Mishnah's Plain Sense. A Study of Modern Talmudic Scholarship”) [Hebrew] (Tel Aviv: Hakibbutz Hameuchad, 2011), 104-118.

70 Cf. David Malkiel, “The Reggios of Gorizia: Modernization in Micro," in The Mediterranean and the Jews, ed. Elliott Horowitz (Ramat Gan: Bar-Ilan University Press, 2002): 73.

71 Akhiezer, Historical Consciousness, 222.

72 Samuel David Luzzatto, Lezioni di Storia Giudaica (Padua: Bianchi, 1852), 21, 83, 145-155 and $166-173$.

73 Ibidem, 147: 'Che sono I caraiti, non già i rabbaniti, quelli che si debbono dire nuovi e riformati giudei. [...] Rispondono i Caraiti che i Talmudisti hanno soventi volte mentovata la loro setta, ma che per odio l'hanno confusa con quella dei Sadducei. Conche alcuni Rabbaniti moderni, spinti o dall'ignoranza, o dall'odio, hanno confusi i Caraiti coi Sadducei.' 
In demonstrating his claim, Luzzatto puts forward four arguments. Firstly, that the Karaites are not mentioned in talmudic literature, secondly, the Karaites do not mention any scholar of their school before Anan in the eighth century, thirdly they have adopted the vocalic system of the rabbanite tradition of the Bible which Luzzatto believed was developed after the fifth century of the common era, and lastly they observe stricter rules than rabbanite Jews in their matrimonial law.

However, without sharing the sympathies of Fernandez and Reggio towards the Karaites, Luzzatto insists that Karaism does not necessarily contrast with what he deems the fundamental principles of faith of Judaism, to which he devotes his book Lezioni di Teologica dogmatica (Trieste: Coen, 1863). In line with his Italian predecessor, Luzzatto attempts to draw an historical portrayal of Judaism which in contradistinction to Christianity, has not been affected by religious schisms. Thus, he dismisses the Samaritans considering them as belonging to the Moabite nation and not to be Jews. Of the Sadducees and the Boethusians Luzzatto insists their weight in Judaism has been almost completely irrelevant. Writing of these sects, active in the Second Temple period he states they were 'always numerically feeble and did not have any public impact. ${ }^{74}$ And as for the last and still existing Jewish sect, the Karaites, after having demolished their claim to antiquity and allegedly superior adherence to the original meaning of the Scriptures, he concludes:

[A]lthough they negate the rabbinical traditions, they do not do it in an absolute manner, since their opposition to the sacred text of the law is only apparent. In reality they admit the immortality of the soul, and in practice they are the most rigid observers of the Law and of the Moral. ${ }^{75}$

Rabbanite Jews and Karaites are united in their basic belief in a common faith and both reject the sceptic attitude of modernity against religion, which is Luzzatto's main polemical target. ${ }^{76}$

In the writings of Aron Fernando, Isaac Samuel Reggio, Samuel David Luzzatto, and others, the Karaite is not the figure of the classical schismatic, as say, the Protestant in the eyes of the Catholic, or the Reformed Jew in those of the Orthodox. In a country such as Italy, that had not experienced the religious divides of other European regions, the Karaites represented instead the fear of the possibility of such a division. Within Italian Judaism that was moving towards a more carefully defined doxology, the doctrinal differences between Karaism and Rabbinical Judaism had to be neutralized. Jews in Italy, reformist leaning or not, wished to maintain a façade of unity. In the words of one of the main political leaders of Italian Jews in the nine-

74 Luzzatto, Il giudaismo illustrato, 37: 'Furono sempre deboli di numero e di credito pubblico.' 75 Ibidem: 'I caraiti poi negano essi le tradizioni rabbiniche, ma non assolutamente, ma in quanto sembrano opporsi al sacro testo della legge; ammettono poi l'immortalità dell'anima, e sono nella pratica i più rigidi osservatori della Legge e della Morale.'

76 Luzzatto considers scepticism and not Karaism the main menace to the unity of the Jewish people and devotes different sections (24 to 27) of his Lezioni di Teologica dogmatica to undermining the spread of this dangerous attitude among his fellow Jews. 
teenth century, Salvatore Anau (1807-1874): 'The world shall be Catholic for the universality of brotherly love!'77 Giuseppe Levi, founder and director of the influential Jewish paper l'Educatore Israelita, gave voice to the same wish most precisely in a long article on the Karaites:

Luckily enough in the bosom of Judaism [...] the word of God remained always one and uniform. [...] Therefore, Judaism in our times walks united, and the different opinions that strife within it, did not become, and we hope, will never become, a sect, distinct and opposed to it. ${ }^{78}$

Therefore, after summarizing its history and doctrines, Levi insists Karaism does not represent a schism within Judaism. On the contrary, 'not the principles, but only some rituals separate between us. [...] it would be nice and useful that the representatives of the great principle of God's unity, should all be united in beautiful harmony. ${ }^{, 79}$

This also explains a reticence in using the word 'reform' which at the time was highly controversial. In Italy, even the most far-reaching Jewish reformers avoided it when describing their intended plans. Moderate or radical reformers, such as Mortara, Salomone Olper (1811-1877), Lelio Cantoni (1802-1857), and many others, preferred to designate themselves as progressives, or as moderate conservatives, and even as orthodox, inventing the category of ultra-orthodox to differentiate their views from the traditionalists they intended to disqualify. Undoubtedly, for Jews living in a Catholic environment, the word 'reform' evoked the schisms provoked within Christianity by Protestantism.

It is certainly worth noting that also in neighbouring Catholic France, the reform movement founded in 1907 adopted the name of Union Libérale and not Union Reformée.

Therefore, for Italian Jews, Karaites became the image of the threat to the Catholic, i.e. universalist, vocation of Judaism. To minimise their role in the historical de-

77 Salvatore Anau, Della emancipazione degli Ebrei (Florence, 1847), 15.

78 Giuseppe Levi, “Alcuni cenni popolari sui caraiti,” L'Educatore Israelita 7 (1859): 290 - 291: 'Fortunatamente però nel seno proprio del Giudaismo [...] la parola di Dio rimase quasi sempre uniforme e sola. [...] Così il giudaismo ai nostri tempi cammina quasi uniforme ed unito, e le varie opinioni che si combattono ora nel suo seno non hanno pero ancora dato luogo e, speriamo, non lo daranno mai ad una setta pienamente distinta e contraria.' The main source of information concerning Karaism seems to be Samuel David Luzzatto, with some additions such as the possibility of the Karaites being the descendants of the lost tribes of Israel. He asks his young readers to imagine a synagogue and Karaite quarter and concludes that nobody would be able to tell the difference in Italian Jewish life, aside from the fact that Karaites are perhaps more rigid in their observance of the law than the descendants of Talmudic Jews, i.e. contemporary Italian Jews.

79 Ibidem, L'Educatore Israelita 8 (1860): 10: 'Non sono principi, ma sono solo alcuni riti che ci separano. [...] sarebbe bello ed utile che i rappresentanti ed eredi del grande principio della Unità di Dio, fossero tutti uniti in bella armonia.' The same conclusion could be found in Fernandez, Progetto, 184: 'the Karaites agree with the other Jews in everything concerning the fundamental principles of religion' ('i caraiti convergono in quanto riguarda i punti fondamentali della religione con gli altri ebrei'). 
velopment of Judaism, stressing that the core of the dogmatic structure of Judaism, was shared by Karaites and Rabbanites, permitted Jews in Italy to find a common ground in fighting what Morais, in his literary portrait of Luzzatto, labelled 'the corrosive effects of indifferentism and scepticism.'

This too explains the transformation of Samuel David Luzzatto into a consensual Jewish icon for all emancipated Jews, notwithstanding their personal positions in the spectrum of attitudes toward religion, tradition, and practice. The strong drive to give a dogmatic foundation to Judaism, one of the major goals of Luzzatto's intellectual endeavour, resulted in a vision of the Jewish political and religious body as fundamentally unified and impermeable to change. In the process, the Karaites' differences to normative Judaism could be domesticated and transform their image from schismatics waiving the banner of scepticism against their fideistic antagonists (as was the case among Jews and Christians alike in a religiously divided Central and Northern Europe) into a branch of the people of Israel, exotic but innocuous, confirming the universality and eternity of the Jewish faith. 
